\title{
The Shoreline Fringe Forest and Adjacent Peatlands of the Southern Central British Columbia Coast
}

\author{
ERIC G. LAMB ${ }^{1}$ AND William MEGILL ${ }^{2}$
} Coastal Ecosystems Research Foundation (CERF) Allison Harbour, P.O. Box 124, Port Hardy, British Columbia V0N 2 P0
Canada

${ }^{1}$ Current address: Department of Biology, University of Alberta, Edmonton, Alberta, T6G 2E9 Canada; e-mail: elamb@ ualberta.ca

${ }^{2}$ Current address: Centre for Biomimetic and Natural Technologies, Department of Mechanical Engineering, University of Bath, BA2 7AY, United Kingdom; e-mail:w.m.megill@bath.ac.uk

Lamb, Eric G., and William Megill. 2003. The shoreline fringe forest and adjacent peatlands of the southern central British Columbia coast. Canadian Field-Naturalist 117(2): 209-217.

Four distinct vegetation types are found in close proximity along an exposed section of the southern central coast of British Columbia. A coastal fringe of coniferous forest a few hundred metres wide is separated by a steep ecotone from an inland peatland-forest complex. The objectives of this study were (1) to describe the plant communities along the transition from forest to peatland, and (2) to identify some of the major environmental factors associated with those communities using indicator plant analysis. The coastal forest is dominated by Thuja plicata, Tsuga heterophylla, Picea sitchensis, and Chamaecyparis nootkatensis. Characteristic understory species include Gaultheria shallon and Blechnum spicant. Inland from the coastal forest are transitional forest stands with a species-rich understory including Cornus canadensis, Hylocomium splendens, and Vaccinium parvifolium. The peatlands are poor fens characterized by thickets of Pinus contorta and Chamaecyparis nootkatensis among open areas dominated by species such as Sphagnum sp., Empetrum nigrum, Juniperus communis, and bogs characterized by Myrica gale, Eriophorum angustifolium, and Sanguisorba officinalis. Indicator plant analysis identified differences in the ground surface materials, soil moisture and nutrient regime between the vegetation types. The general trend is for an increase in soil moisture from the forest vegetation to the peatlands and a concurrent change from the Mor humus forms that dominate the coastal forest floor to the surface groundwater table of the peatlands. These environmental differences between forest and peatland are likely related to the steeper slopes typically found in the fringe forest vegetation.

Key Words: British Columbia central coast, ecotone, peatland, Indicator Species Analysis, Indicator Plant Analysis, NonMetric Multidimensional Scaling, species distribution.

The Hecate Lowlands of the southern central British Columbia coast are dominated by a complex of dense coniferous forest and open peatlands. Along the outer coast, the peatlands are typically separated from the ocean by a narrow strip of dense coniferous forest. This coastal fringe forest is frequently less than 200 meters wide, terminating in a scrub forest ecotone separating it from the inland peatlands. The fringe forests of the British Columbia coast have rarely been discussed; most research on this vegetation type has been concentrated in southern Alaska (Zach 1950; Neiland 1971). The dominant peatland communities of the outer British Columbia coast have traditionally been classified as slope bogs (Banner et al. 1988), though more recent research indicates that in many cases they should be considered poor fens (Vitt et al. 1990). The successional relationships between forest and peatland in the region have been extensively studied (e.g., Zach 1950; Lawrence 1958; Ugolini and Mann 1979; Banner et al. 1983; Klinger et al. 1990), but only Neiland (1971) has carefully examined the ecotone between the forests and peatlands. The studies of the peatland-forest complex that have been done have rarely included sites directly exposed to the open ocean, leaving a major element of the coastal landscape very poorly understood. The fringe forests along exposed coastlines are also of interest because at many sites they have been subject to very little human disturbance, thus natural processes have not been influenced by human management practices.

This paper is an investigation into the vegetation patterns in the coastal fringe forests, adjacent peatlands, and the peatland-forest ecotone of a section of the southern Central Coast of British Columbia. The exposed coastlines of the region have been very poorly explored botanically, so the objectives of this study were (1) to identify the major plant communities along the transition from forest to peatland, and (2) to identify major environmental factors associated with those communities.

\section{Study Area}

The study area is a $30-\mathrm{km}$ stretch of the southern central coast of British Columbia between Seymour Inlet and Smith Sound $\left(51^{\circ} 02^{\prime} \mathrm{N} 127^{\circ} 31^{\prime} \mathrm{W}\right.$ to $51^{\circ} 13^{\prime} \mathrm{N}$ $\left.127^{\circ} 55^{\prime} \mathrm{W}\right)$. The region is provincially classified as the Coastal Western Hemlock biogeoclimatic zone (Pojar et al. 1991), and nationally as the Coastal Gap ecoregion of the Pacific Maritime ecozone (Marshall and Schut 1999*). The peatlands have traditionally been described as slope bog communities in the Pacific Oceanic Wetland Subregion (Banner et al. 1988), 
though more recent work indicates that many sites receive nutrients from groundwater sources and therefore should be considered poor fens (Vitt et al. 1990).

The coastline is rugged, with a mixture of rocky cliffs, boulder beaches, and occasional sand beaches facing Queen Charlotte Strait. The land typically rises from the shore with moderate to steep slopes, but quickly flattens into rolling uplands dotted with bedrock outcrops. Substrates are typically intrusive igneous rock (Ryder 1978), and the soils moist to wet Ferro-Humic Podzols that rarely freeze in winter (Jungen and Lewis 1978). The climate is cool, wet, and windy. At the Egg Island light station $\left(51^{\circ} 15^{\prime} \mathrm{N}\right.$ $\left.127^{\circ} 50^{\prime} \mathrm{W}\right)$ mean annual temperature is $8.2^{\circ} \mathrm{C}$ and mean annual precipitation is $2484 \mathrm{~mm}$ (Atmospheric Environment Service 1982*). Mean monthly temperature is lowest in January $\left(3.4^{\circ} \mathrm{C}\right)$ and highest in August $\left(13.4^{\circ} \mathrm{C}\right)$. Mean monthly precipitation ranges from $82 \mathrm{~mm}$ in July to $366 \mathrm{~mm}$ in December. Even in January only $10 \%$ of the precipitation falls as snow.

\section{Methods}

Field

Vegetation sampling for this study was carried out in the summer of 1999 along transects extending inland from 19 shoreline sites selected to represent a range of coastal features and wave exposure levels for an intertidal biodiversity study (Lamb et al. 2000*). All sites selected for this study are highly exposed and have low to moderate relief inland. At each study site a $300 \mathrm{~m}$ transect was laid out along a compass bearing approximately perpendicular to the shoreline. The shoreward end of the transect was located at the first vascular vegetation above the high tide line. Sampling was carried out at distances of $20 \mathrm{~m}, 50 \mathrm{~m}, 100 \mathrm{~m}$, $200 \mathrm{~m}$, and $300 \mathrm{~m}$ along the transect. The sampling intensity was greater in the first $100 \mathrm{~m}$ to capture the perceived rapid change in forest composition very near the shore. Intervals were increased between quadrats toward the inland end of the transects, where the change in composition was slower, to ensure that the full range of vegetation, from coastal forest to inland peatland, could be sampled in one day. At each location pairs of $2 \mathrm{~m}$ by $2 \mathrm{~m}$ quadrats were placed $10 \mathrm{~m}$ to either side of the transect, for a total of 190 quadrats. Each quadrat was surveyed for bryophytes, herbaceous plants, and shrubs. Vascular plants were identified to species with the exception of some difficult genera such as Carex and Listera; bryophytes were identified to genus with the exception of Hylocomium splendens. Percent cover was estimated using the Braun-Blanquet six-point cover scale (Kent and Coker 1992). Nomenclature follows Douglas et al. (1998; 1999; 2000; 2001; 2002) for vascular plants and Schofield (1992) for the bryophytes. Shrubs and small trees included any woody plant less than $5 \mathrm{~cm} \mathrm{DBH}$ (diameter at breast height). Four trees greater than $5 \mathrm{~cm}$ DBH surrounding each plot were sampled using the point-quarter method (Krebs 1989).

\section{Data Analysis}

The overall trends in these data were examined using a Non-Metric Multidimensional Scaling (NMS) ordination. NMS is a non-parametric ordination method well suited to community data because it avoids many of the assumptions about the underlying structure of the data made by traditional ordination methods (Kenkel and Orlóci 1986; McCune and Grace 2002). The autopilot program in the PC-Ord program (McCune and Mefford 1999), with the slow and thorough analysis option, Sorenson distance, and the default settings selected, was used for the analysis. Rare species (observed in fewer than five quadrats) were eliminated prior to analysis.

Since four broad vegetation types were subjectively observed during fieldwork, quadrats were classified into four groups using a hierarchical cluster analysis (Ward's Method using Euclidean distance). Ward's method is recommended as an effective classification tool for community data (McCune and Grace 2002). Species that were significantly more frequent and abundant in each of the four groups of quadrats were identified using Indicator Species Analysis (Dufrêne and Legendre 1997). Indicator values are calculated by multiplying the relative abundance of each species in a particular group by the relative frequency of the species' occurrence in that group. The significance of the observed indicator values are evaluated using a Monte Carlo simulation of 1000 runs where samples are randomly reassigned to groups and indicator values recalculated. PC-Ord (McCune and Mefford 1999) was used for these analyses.

Tree stem density, mean basal area per stem, and species importance values were calculated for each vegetation type. Tree density and $95 \%$ confidence limits were calculated from the Point-Quarter data following Krebs (1989). The Importance Values for each tree species in each vegetation type were calculated following Kent and Coker (1992). Importance values are the sum of the relative density (number of individuals of a species/total number of individuals) $\times 100$, the relative dominance (mean basal area per tree of a species $\times$ number of trees of that species)/(mean basal area per tree of all species/total number of trees) $\times 100$, and the relative frequency (proportion of plots containing a species $) \times 100$. Ln-transformed mean basal area per stem (of the four stems measured at each plot) was compared between the four vegetation types using an ANOVA followed by a post-Tukey test. Only basal area was compared using ANOVA since the measures of density and Importance Values are aggregate values calculated from all of the plots in a vegetation type, and hence cannot be compared using statistical tests such as ANOVA.

The environmental conditions of the four vegetation types were explored using the spectral method of Indicator Plant Analysis (Klinka et al. 1989). Indicator plant analysis is based on the observation that many 
species require very specific environmental conditions and that the presence of a group of species with similar tolerances in high abundance at a site is a strong indication that those conditions prevail at that site. Indicator plant analysis was used as an alternative to costly and labor-intensive soil sample collection and analysis. Indicator species analysis can be used to estimate the soil moisture regime (MOIST), soil nutrient regime (NITR), and the type of ground surface materials present $(\mathrm{GSM})$. Each environmental factor is divided into several categories, or "Indicator Plant Groups"; species with a relatively narrow range of tolerance for that environmental factor are assigned to the appropriate Indicator Plant Group. Species with wide tolerances for a particular factor are generally not used as indicators. Klinka et al. (1989) provide extensive lists of species from coastal British Columbia that fall into the Indicator Plant Groups for each environmental factor.

There are four steps to an indicator plant analysis. First, the mean abundance for each species across all of the quadrats in each vegetation type is calculated. Second, the species are divided into their respective indicator plant groups, and the abundances of all species belonging to each group are summed. Third, the proportion of the total species abundance in each vegetation type that each indicator plant group makes up is calculated. Finally, these proportions are used to estimate the actual range of values that an environmental factor takes in a vegetation type by following the tables and keys provided in Klinka et al. (1989). A reliability ratio, or the proportion of species in a vegetation type, that are useful as indicators for a particular environmental variable is calculated. A low reliability ratio indicates that many of the species in a community either are generalists or have not been screened for their potential as indicators.

Slope was compared between the coastal forest and the transition and peatland vegetation types. Direct measurements of slope were not taken in the field, so estimates from large-scale topographic maps were used instead. The average percent slope was estimated along each transect from the distance between $20 \mathrm{~m}$ contour intervals on 1:20 000 Terrain Resource Inventory Maps (TRIM). Each quadrat was assigned the slope estimated for that segment of the transect. Quadrats that fell on a contour line were assigned the average of the slopes of the segments above and below them. Mean slopes were compared between the four vegetation types using a one-way ANOVA followed by a post-hoc Dunnet's T3 test. Variances were unequal and could not be improved by transformation, so the post-hoc T3 test, which does not assume equal variances, was used instead of a Tukey test (Day and Quinn 1989).

\section{Results and Discussion}

Nineteen sites and 190 quadrats were sampled in the field. The NMS produced a 2-dimensional solution with a final stress of 19.655 (Figure 1). The first ordination axis accounts for $46.7 \%$ of the variation in the species data and the second $35.8 \%$ for a cumulative $\mathrm{r}^{2}$ of 0.825 . Species with a substantial amount of variation $\left(r^{2}>0.100\right)$ explained by at least one of the two axes are listed in Table 1. The first axis separates quadrats with a high abundance of Gaultheria shallon and Rhytidiadelphus sp. from quadrats with a high abundance of Eriophorum angustifolium, Juniperus communis, Myrica gale, Sphagnum sp., and Trichophorum caespitosum. The second axis separates quadrats with a high abundance of Blechnum spicant, Gaultheria shallon, Kindbergia sp., and Plagiothecium sp. from quadrats with a high abundance of Empetrum nigrum, Eriophorum angustifolium, Juniperus communis, Kalmia microphylla, Ledum groenlandicum, Myrica gale, Pinus contorta, Sphagnum sp., and Trichophorum caespitosum. Together these two axes delineate a clear gradient from forest vegetation to open peatland. Since the two axes explain a large proportion of the variation in the species data $\left(r^{2}=0.825\right)$, this ecotone is the major feature of this community.

The cluster analysis divided the quadrats into four groups corresponding to the four vegetation zones subjectively observed in the field (Figure 1). With few exceptions, the quadrats classified into each vegetation type are closely grouped together in the ordination diagram. The Coastal Fringe Forest type has a closed canopy of large trees with a dense to open shrub and bryophyte dominated understory. The Transitional Forest type has an open canopy with a very extensive shrub understory. The Dry Peatland type supports small thickets of trees among open ericaceous heaths, while the Wet Peatland type is dominated by Myrica gale. The majority $(87 \%)$ of the quadrats surveyed $20 \mathrm{~m}$ and $50 \mathrm{~m}$ from the shore were classified as Fringe Forest. The transition between forest and peatland generally fell between $100 \mathrm{~m}$ and $300 \mathrm{~m}$ from the shore, while at eleven sites Fringe Forest vegetation was present at the inland end of the transect.

Species that are significantly more frequent and abundant in the understory plant community of one of the four vegetation types are summarized in Table 2. The Coastal Fringe Forest understory is dominated by a mixture of ericaceous shrubs, ferns, and bryophytes. Common species include Blechnum spicant, Gaultheria shallon, Rubus pedatus, and several bryophytes including Kindbergia sp., Hookeria sp., and Plagiothecium sp. In contrast, species such as Ledum groenlandicum, Fauria crista-galli, Kalmia microphylla, Trichophorum caespitosum, Myrica gale, Juniperus communis, Eriophorum angustifolium and Sphagnum sp. dominate the peatlands. The majority of the species characteristic of the Fringe Forest and the peatlands co-occur in the Transitional Forest, and several common species, including Cornus canadensis, Hylocomium splendens, Linnaea borealis, and Maianthemum dilatatum, are significantly more frequent and abundant there. 


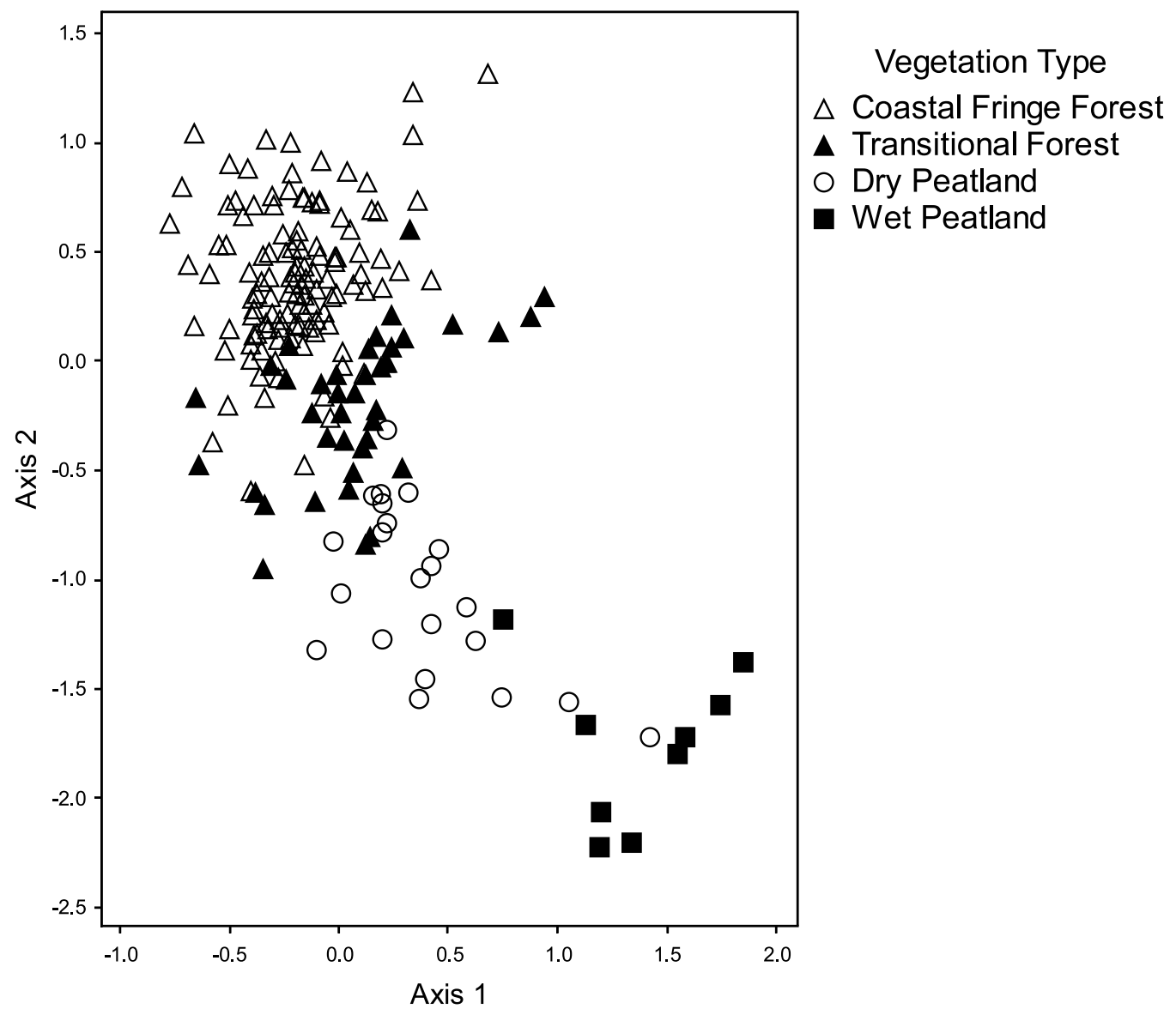

FIGURE 1. NMS ordination of the plant cover data with the four vegetation types from the cluster analysis overlain.

The plant communities identified in the classification are similar to the south-east Alaska plant communities described by Neiland (1971). For example, she described a forest community found on steeper slopes fronting the ocean that had many understory species, including Rhytidiadelphus sp. and Vaccinium parvifolium, in common with the Coastal Fringe and Transitional forest types. The Transitional Forest and the Dry Peatland types observed in this study should be classified as types of slope bog (Banner et al. 1988), but the frequency of Chamaecyparis nootkatensis in those vegetation types (Table 2;3) indicates that this classification may be incorrect. C. nootkatensis is an indicator of soligenous fens that receive mineral nutrients from groundwater sources in addition to rain deposition (Vitt et al. 1990), suggesting that many of the peatlands on the central coast may be poor fens. The species composition of the Wet Peatland community is consistent with the slope bog descriptions in Banner et al. (1988), and the absence of $C$. nootkatensis from this vegetation type indicates that this vegetation type should be considered a true bog.

There is a significant decline in mean basal area per stem $(\mathrm{F}=16.812 ; \mathrm{P}<0.001)$ from the Coastal Fringe Forest to the peatlands (Figure 2). Stem densities, however, are very similar between the Fringe Forest, Transitional Forest, and Dry Peatland vegetation types (Figure 2). The large confidence intervals around mean basal area in the Transitional Forest, and especially in the Coastal Fringe Forest, reflect the great variation in tree sizes found there. For example, the diameters of the largest individuals of the four major tree species observed were Chamaecyparis nootkatensis $(0.65 \mathrm{~m})$, Picea sitchensis $(1.67 \mathrm{~m})$, Thuja plicata $(1.49 \mathrm{~m})$, and Tsuga heterophylla $(1.03 \mathrm{~m})$. Small, suppressed individuals were common in the understory and vigorous saplings were common in canopy gaps. The Dry Peatland supports many of the same tree species as the Transitional forest, but Pinus contorta is much more important. The Wet Peatland vegetation is characterized 
TABLE 1. Species axis scores and Pearson correlations between species abundance and axis scores from the NMS ordination. Only species with an $\mathrm{r}^{2}>0.100$ on at least one axis are listed.

\begin{tabular}{|c|c|c|c|c|c|c|c|}
\hline \multirow[t]{2}{*}{ Species } & \multirow[t]{2}{*}{ Common Name } & \multicolumn{3}{|c|}{ Axis 1} & \multicolumn{3}{|c|}{ Axis 2} \\
\hline & & Score & $\mathrm{r}$ & $\mathrm{r}^{2}$ & Score & $\mathrm{r}$ & $\mathrm{r}^{2}$ \\
\hline Blechnum spicant & Deer Fern & -0.116 & -0.253 & 0.064 & 0.300 & 0.427 & 0.182 \\
\hline Chamaecyparis nootkatensis & Yellow Cedar & 0.170 & 0.128 & 0.016 & -0.791 & -0.389 & 0.152 \\
\hline Drosera rotundifolia & Round -Leafed Sundew & 0.383 & 0.173 & 0.03 & -1.138 & -0.335 & 0.113 \\
\hline Empetrum nigrum & Crowberry & 0.329 & 0.308 & 0.095 & -1.047 & -0.64 & 0.409 \\
\hline Eriophorum angustifolium & Narrow-Leafed Cotton Grass & 1.364 & 0.611 & 0.373 & -1.722 & -0.504 & 0.254 \\
\hline Fauria crista-galli & Deer Cabbage & 0.397 & 0.253 & 0.064 & -1.024 & -0.427 & 0.182 \\
\hline Gaultheria shallon & Salal & -0.137 & -0.58 & 0.336 & 0.255 & 0.702 & 0.493 \\
\hline Grass & & 0.146 & 0.149 & 0.022 & -0.486 & -0.324 & 0.105 \\
\hline Juniperus communis & Common Juniper & 0.988 & 0.642 & 0.412 & -1.608 & -0.683 & 0.467 \\
\hline Kalmia microphylla & Bog Laurel & 0.582 & 0.473 & 0.223 & -1.219 & -0.647 & 0.418 \\
\hline Kindbergia sp. & & -0.010 & -0.278 & 0.077 & 0.291 & 0.528 & 0.279 \\
\hline Ledum groenlandicum & Labrador Tea & 0.124 & 0.162 & 0.026 & -0.710 & -0.606 & 0.367 \\
\hline Myrica gale & Sweet Gale & 1.113 & 0.679 & 0.461 & -1.498 & -0.597 & 0.356 \\
\hline Oxycoccus oxycoccos & Bog Cranberry & 0.878 & 0.327 & 0.107 & -1.341 & -0.327 & 0.107 \\
\hline Pinus contorta & Shore Pine & 0.526 & 0.347 & 0.12 & -1.262 & -0.543 & 0.295 \\
\hline Plagiothecium sp. & & -0.115 & -0.242 & 0.059 & 0.303 & 0.417 & 0.174 \\
\hline Racomitrium sp. & & 0.668 & 0.364 & 0.133 & -1.565 & -0.558 & 0.311 \\
\hline Rhytidiadelphus sp. & & -0.126 & -0.434 & 0.189 & 0.147 & 0.331 & 0.109 \\
\hline Sanguisorba officianalis & Great Burnet & 1.424 & 0.68 & 0.462 & -1.699 & -0.53 & 0.281 \\
\hline Sphagnum sp. & & 0.432 & 0.66 & 0.436 & -0.644 & -0.643 & 0.413 \\
\hline Tofieldia glutinosa & Sticky False Asphodel & 0.836 & 0.358 & 0.128 & -1.626 & -0.455 & 0.207 \\
\hline Trichophorum caespitosum & Tufted Clubrush & 0.958 & 0.606 & 0.367 & -1.546 & -0.638 & 0.408 \\
\hline Trientalis arctica & Northern Starflower & 0.707 & 0.288 & 0.083 & -1.490 & -0.396 & 0.157 \\
\hline Vaccinium sp. & & 0.437 & 0.191 & 0.037 & -1.330 & -0.38 & 0.145 \\
\hline Vaccinium uliginosum & Bog Blueberry & 0.893 & 0.338 & 0.114 & -1.644 & -0.406 & 0.165 \\
\hline Vaccinium vitis-idaea & Lingonberry & -0.001 & -0.001 & 0 & -0.502 & -0.394 & 0.155 \\
\hline
\end{tabular}

by scattered "bonsai" Pinus contorta. The Coastal Fringe Forest tree community is more species rich than the other vegetation types, as small numbers of Taxus brevifolia and Malus fusca were sampled there and individuals of two much rarer species, Abies amabilis and Alnus rubra, were encountered.

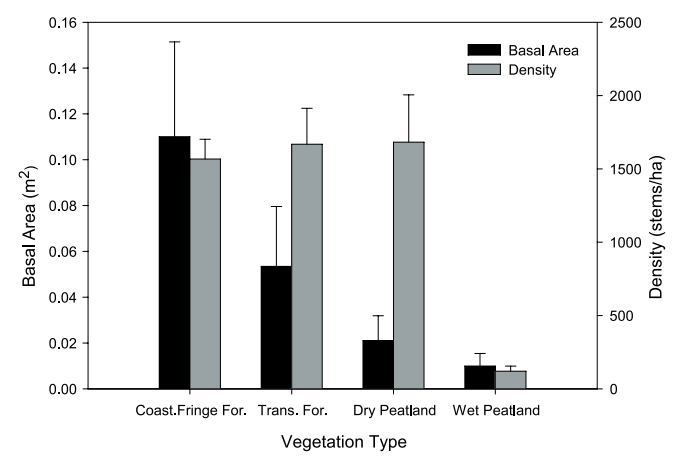

FIGURE 2. Stem density/ha and basal area/stem in each vegetation type. Basal areas were significantly larger $(\mathrm{p}<$ 0.05 ) in the Coastal and Transitional forests than in the Peatland types. Error bars are 95\% confidence intervals.
Indicator plant analysis was performed to estimate the soil moisture regime, soil nutrient regime, and ground surface materials found in the four vegetation types (Table 3). The MOIST6 soil indicator group is dominant in all but the Coastal Fringe Forest, indicating an overall wet moisture regime. In the Fringe Forest the MOIST4 group is dominant and the MOIST5 group well represented, indicating a moist soil moisture regime. A moist regime is found on sites where water deficits do not normally occur and the groundwater table is normally between 30 and $60 \mathrm{~cm}$ deep or deeper (Klinka et al. 1989). Species from other indicator plant groups are also found, such as the MOIST2 group solely represented in the Wet and Dry Peatlands by Juniperus communis. Species from the GSM1 group, indicating Mor humus forms, or a layer of compacted organic material greater than $5 \mathrm{~cm}$ thick overlying the mineral soil, were present in all four vegetation types. These species were dominant in all but the Wet Peatland type. Species from the GSM5 group, indicating a surface groundwater table, were dominant in the Wet Peatland and well represented in the Dry Peatland. The NITR1 group (indicating poor to very poor soils) is dominant in the Fringe Forest, Transitional Forest, and Dry Peatland vegetation types, and well represented in the Wet Peatland. The NITR2 group (indicating medium soils) is dominant in the 
TABLE 2. Indicator Values (IV) of common understory species significantly more frequent and abundant $(\mathrm{P}<0.100)$ in one of the four vegetation types. Species are grouped by the vegetation types in which they have the highest indicator values. The maximum possible observed indicator value is 100 . The mean randomized indicator values are calculated for the group with the highest observed indicator value from a Monte-Carlo simulation of 1000 runs. The P-value is the proportion of the randomized runs that produced an indicator value higher than the observed indicator value.

\begin{tabular}{|c|c|c|c|c|c|c|c|c|}
\hline \multirow[b]{2}{*}{ Species } & \multirow[b]{2}{*}{ Common Name } & \multicolumn{4}{|c|}{ Observed Indicator Values } & \multirow[b]{2}{*}{$\begin{array}{l}\text { Rand } \\
\text { IV }\end{array}$} & \multirow[b]{2}{*}{$\begin{array}{c}\text { SD } \\
\text { Rand IV }\end{array}$} & \multirow[b]{2}{*}{$V \quad \mathrm{P}$} \\
\hline & & $\begin{array}{l}\text { Fringe } \\
\text { Forest }\end{array}$ & $\begin{array}{l}\text { Trans. } \\
\text { Forest }\end{array}$ & $\begin{array}{c}\text { Dry } \\
\text { Peatland }\end{array}$ & $\begin{array}{c}\text { Wet } \\
\text { Peatland }\end{array}$ & & & \\
\hline \multicolumn{9}{|l|}{ Coastal Fringe Forest } \\
\hline $\begin{array}{l}\text { Blechnum splcant } \\
\text { Gaultheria shallon }\end{array}$ & $\begin{array}{l}\text { Deer Fern } \\
\text { Salal }\end{array}$ & 47 & $\begin{array}{l}18 \\
35\end{array}$ & $\begin{array}{r}4 \\
13\end{array}$ & 0 & $\begin{array}{l}20.1 \\
26.8\end{array}$ & $\begin{array}{l}4.24 \\
2.03\end{array}$ & $\begin{array}{r}0.008 \\
<0.001\end{array}$ \\
\hline Hookeria sp. & & 18 & 3 & 0 & 0 & 10.2 & 4.47 & 0.057 \\
\hline Kindbergia sp. & & 47 & 28 & 7 & 0 & 25.4 & $3.28<$ & $<0.001$ \\
\hline Leafy Liverwort & & 32 & 14 & 1 & 1 & 19.7 & 4.29 & 0.018 \\
\hline Plagiothecium sp. & & 40 & 31 & 1 & 0 & 23.3 & 4.26 & 0.006 \\
\hline Rhizomnium sp. & & 22 & 18 & 0 & 0 & 15.6 & 4.63 & 0.084 \\
\hline Rubus pedatus & Five-leafed Bramble & 17 & 2 & 0 & 0 & 9.7 & 4.51 & 0.069 \\
\hline \multicolumn{9}{|l|}{ Transitional Forest } \\
\hline Cornus canadensis & Bunchberry & 16 & 38 & 27 & 3 & 24.5 & 3.53 & 0.002 \\
\hline Dicranum sp. & & 19 & 27 & 19 & 0 & 21.8 & 3.96 & 0.091 \\
\hline Hylocomium splendens & & 25 & 42 & 11 & 0 & 23.8 & 3.94 & 0.002 \\
\hline Linnaea borealis & Twinflower & 6 & 29 & 26 & 0 & 16.9 & 4.44 & 0.019 \\
\hline Maianthemum dilatatum & False Lily-of-the-Valley & 13 & 31 & 7 & 0 & 17.6 & 4.42 & 0.017 \\
\hline Menziesia ferruginea & False Azalea & 28 & 32 & 0 & 0 & 19.3 & 4.66 & 0.029 \\
\hline Rhytidiadelphus sp. & & 38 & 39 & 15 & 0 & 26.3 & 2.59 & $<0.001$ \\
\hline Thuja plicata* & Western Red Cedar & 6 & 24 & 16 & 0 & 14.7 & 4.59 & 0.049 \\
\hline Vaccinium parvifolium & Red Huckleberry & 28 & 36 & 3 & 0 & 22.1 & 4.23 & 0.007 \\
\hline Herbertus sp. & & 0 & 15 & 3 & 0 & 7.2 & 3.97 & 0.046 \\
\hline Thallose Liverworts & & 0 & 11 & 0 & 0 & 5.5 & 3.19 & 0.051 \\
\hline \multicolumn{9}{|l|}{ Dry Peatland } \\
\hline Carex pauciflora & Few-Flowered Sedge & 0 & 1 & 15 & 2 & 5.1 & 3.09 & 0.018 \\
\hline Chamaecyparis nootkatensis* & Yellow Cedar & 0 & 10 & 29 & 0 & 8.8 & 4.28 & 0.005 \\
\hline Drosera rotundifolia & Round-Leafed Sundew & 0 & 2 & 15 & 9 & 6.3 & 3.72 & 0.042 \\
\hline Empetrum nigrum & Crowberry & 0 & 3 & 57 & 17 & 11 & 4.52 & $<0.001$ \\
\hline Fauria crista-galli & Deer Cabbage & 0 & 1 & 19 & 14 & 7.5 & 3.98 & 0.028 \\
\hline Kalmia microphylla & Western Bog Laurel & 0 & 0 & 48 & 30 & 9.2 & $4.25<$ & $<0.001$ \\
\hline Ledum groenlandicum & Labrador Tea & 0 & 16 & 47 & 9 & 14 & 4.47 & $<0.001$ \\
\hline Microseris borealis & Apargidium & 0 & 0 & 27 & 0 & 4.7 & 3.22 & 0.002 \\
\hline Oxycoccus oxycoccos & Bog Cranberry & 0 & 0 & 17 & 3 & 4.7 & 3.07 & 0.015 \\
\hline Pteridium aquilinum & Bracken Fern & 3 & 11 & 22 & 0 & 12.1 & 4.64 & 0.050 \\
\hline Trientalis arctica & Northern Starflower & 0 & 0 & 13 & 10 & 4.9 & 3.02 & 0.035 \\
\hline Vaccinium sp. & & 0 & 0 & 36 & 0 & 5.2 & 3.32 & $<0.001$ \\
\hline Vaccinium vitis-idaea & Lingonberry & 0 & 33 & 44 & 0 & 13.8 & 4.36 & 0.002 \\
\hline Lycopodium clavatum & Running Clubmoss & 0 & 0 & 14 & 0 & 3.5 & 2.41 & 0.004 \\
\hline \multicolumn{9}{|l|}{ Wet Peatland } \\
\hline Carex sp. & & 4 & 7 & 13 & 26 & 14.6 & 4.45 & 0.032 \\
\hline Eriophorum angustifolium & Narrow-Leafed Cotton Grass & ss 0 & 0 & 1 & 71 & 5.8 & 3.58 & $<0.001$ \\
\hline Juniperus communis & Common Juniper & 0 & 0 & 9 & 70 & 7.5 & 4.1 & $<0.001$ \\
\hline Myrica gale & Sweet Gale & 0 & 0 & 4 & 84 & 7.1 & 4.17 & $<0.001$ \\
\hline Pinus contorta & Shore Pine & 0 & 0 & 26 & 26 & 7.7 & 4.24 & 0.005 \\
\hline Racomitrium sp. & & 0 & 0 & 12 & 37 & 6.8 & 4.26 & 0.002 \\
\hline Sanguisorba officinalis & Great Burnet & 0 & 0 & 0 & 96 & 6.1 & $3.73<$ & $<0.001$ \\
\hline Sphagnum sp. & & 0 & 22 & 34 & 37 & 16.4 & 4.3 & 0.003 \\
\hline Tofieldia glutinosa & Sticky False Asphodel & 0 & 0 & 3 & 35 & 5.2 & $3.17<$ & $<0.001$ \\
\hline Trichophorum caespitosum & Tufted Clubrush & 0 & 0 & 10 & 58 & 7.2 & $3.99<$ & $<0.001$ \\
\hline Vaccinium uliginosum & Bog Blueberry & 0 & 0 & 8 & 32 & 5.5 & 3.34 & $<0.001$ \\
\hline
\end{tabular}

Wet Peatland. These values indicate a poor nutrient regime in the Fringe Forest and Dry Peatland, poor to very poor in the Transitional Forest, and very poor in the Wet Peatland (Klinka et al. 1989).
The indicator plant analysis provides a general outline of the environmental conditions in each of the four vegetation types, but due to the low reliability ratios the results should be considered very preliminary. The 
TABLE 3. Relative importance values (relative density + relative dominance + relative frequency) for each of the tree species found in each of the four vegetation types. These values reflect the prominence of a particular species in a vegetation type relative to the other species; large values do not necessarily indicate high overall stem density or basal area per stem.

\begin{tabular}{|c|c|c|c|c|}
\hline Species & Coastal Forest & Transitional Forest & Dry Peatland & Wet Peatland \\
\hline Alnus crispa (Sitka Alder) & 4.23 & 0 & 0 & 0 \\
\hline Chamaecyparis nootkatensis (Yellow Cedar) & 35.65 & 75.73 & 87.31 & 0 \\
\hline Malus fusca (Pacific Crab-Apple & 2.81 & 0 & 0 & 0 \\
\hline Picea sitchensis (Sitka Spruce) & 53.23 & 22.71 & 0 & 0 \\
\hline Pinus contorta (Shore Pine) & 16.78 & 18.20 & 125.23 & 233.39 \\
\hline Snag & 99.49 & 97.38 & 132.42 & 110.46 \\
\hline Taxus brevifolia (Pacific Yew) & 2.19 & 0 & 0 & 0 \\
\hline Thuja plicata (Western Red Cedar) & 116.89 & 133.55 & 78.84 & 33.93 \\
\hline Tsuga heterophylla (Western Hemlock) & 128.73 & 126.78 & 48.91 & 0 \\
\hline
\end{tabular}

reliability ratios are low due to the sampling procedure, as many of the species only identified to genus could not be used as indicators. Two genera that were not identified to species, Carex and Sphagnum, are often good indicators of environmental conditions in peatlands (Klinka et al. 1989). These species made up a substantial proportion of the cover in this study, and their inclusion in the indicator plant analysis would substantially increase the reliability ratios. It is unlikely, however, that the trends in environmental conditions identified in the indicator species analysis would be altered if more species were included. The species of Carex and Sphagnum that we most likely encountered in the peatlands are indicators of conditions similar to those suggested by the forb and shrub species.

The most general environmental trend over the forest - peatland transition is an increase in soil moisture levels. This increase correlates with the indications for ground surface materials. Those show a distinct change from the Mor humus forms that dominate the Fringe Forest floor to the surface groundwater table of the Wet Peatland. The only anomaly in the moisture trend is the occurrence of the MOIST2 indicator plant group (moderately to very dry) in the Wet and Dry Peatlands. This group is represented solely by Juniperus communis, and illustrates the environmental heterogeneity found at small scales in these habitats. The lowest areas of the Wet Peatland frequently develop standing pools of water during rainy weather, but among the pools are hummocks and small hillslopes that support Juniperus communis in the otherwise wet habitat. Vitt et al. (1990) found Juniperus in similar raised habitats on the northern British Columbia coast. In contrast to the other environmental factors, there are no clear trends in the soil nutrient regime between the four vegetation types. It is clear that the overall soil nutrient regime in the study area is poor to very poor, but finer differences between the vegetation types cannot be clearly distinguished. The source of water at any particular site in the peatlands (groundwater vs. rainwater) is important (Vitt et al. 1990), and it is likely that a great deal of small-scale variation within each vegetation type is due to small differences in drainage.
Mean estimated slopes were significantly higher in the Fringe and Transitional forests than in the peatlands $(\mathrm{F}=3.179 ; \mathrm{P}=0.012)$ (Figure 3). These steeper slopes in the forested vegetation types are in accord with the observations of Zach (1950) and Neiland (1971). For example, Neiland (1971) found that the mean slope of sites in the coastal forest was approximately $30 \%$ with some sites occurring on slopes of up to $60 \%$. In contrast, she found ecotonal bog-forests generally to be on slopes between $15 \%$ and $20 \%$ to a maximum of $40 \%$, and bogs generally on slopes of less than $10 \%$. Those authors considered increased drainage on the steeper slopes to be the major environmental factor distinguishing forest from peatland vegetation, a conclusion supported by the drier Fringe Forest soils (Table 3). Better drainage on steeper slopes is clearly not a complete answer, as Banner et al. (1988) report that treed slope bogs can be found on slopes of up to $70 \%$. Soil saturation resulting from Sphagnum development (Lawrence 1958) and the development of soil layers that limit drainage (Ugolini and Mann 1979) have been proposed as mechanisms for the conversion of forest to bog along the Pacific Coast. It is likely that long-term

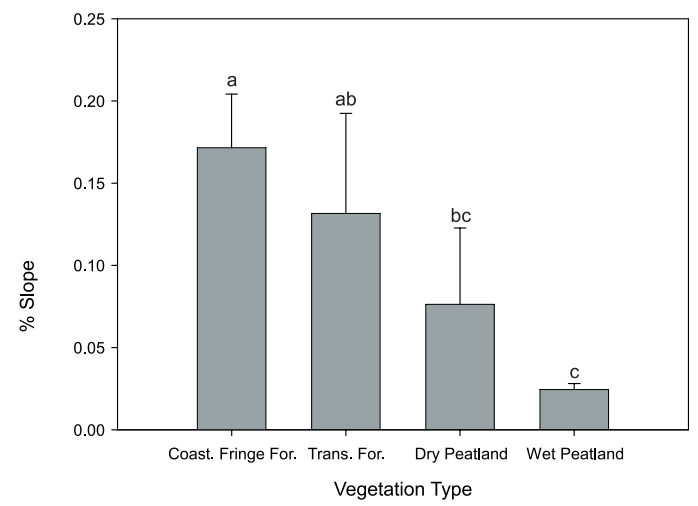

FIGURE 3. Mean slope in each of the four vegetation types. Error bars are $95 \%$ confidence intervals, and letters indicate significant differences $(\mathrm{P}<0.05)$. 
TABle 4. Percentage of the total species abundance in each vegetation type comprised of species that fall into separate Indicator Plant Groups for three main environmental factors: soil moisture (MOIST), soil nutrients (NITR), and ground surface materials (GSM). The explanation of each indicator plant group describes the range of environmental conditions to which species belonging to that group are typically associated. The reliability ratio (Rel Ratio) is the proportion of the total species abundance in a particular vegetation type that is made up by species that are useful as indicators for that environmental factor (Klinka et al. 1989).

\begin{tabular}{lccccl}
\hline \hline Indicator Group & Coastal Forest & Transitional Forest & Dry Peatland & Wet Peatland & Explanation \\
\hline MOIST 1 & 0 & 0 & 0 & 0 & very to excessively dry \\
MOIST 2 & 0 & 0.05 & 8.70 & 23.58 & moderately to very dry \\
MOIST 3 & 3.79 & 12.14 & 5.52 & 0 & fresh to moderately dry \\
MOIST 4 & 69.53 & 36.03 & 3.73 & 0.25 & very moist to fresh \\
MOIST 5 & 16.53 & 10.31 & 28.34 & 19.62 & wet to very moist \\
MOIST 6 & 10.15 & 41.47 & 53.71 & 56.54 & very wet to wet \\
Rel Ratio & 0.19 & 0.14 & 0.26 & 0.57 & \\
NITR 1 & 90.13 & 92.91 & 80.58 & 37.15 & very poor to poor \\
NITR 2 & 0.05 & 0.59 & 10.35 & 62.80 & medium \\
NITR 3 & 9.82 & 6.51 & 9.07 & 0.05 & rich to very rich \\
Rel Ratio & 0.57 & 0.42 & 0.43 & 0.60 & Mor humus forms \\
GSM 1 & 89.8 & 81.94 & 57.97 & 11.70 & Moder and Mull humus forms \\
GSM 2 & 3.59 & 8.95 & 0.06 & exposed mineral soils \\
GSM 3 & 0 & 0 & 0 & 0 & shallow soil over \\
GSM 4 & 0.03 & 0 & 0 & & 0 \\
& & & 33.08 & 88.25 & bedrock fragments \\
GSM 5 & 3.41 & 14.46 & 0.43 & 0.45 & surface groundwater table \\
Rel Ratio & 0.56 & 0.40 & & & \\
\hline \hline
\end{tabular}

successional processes associated with climactic variations and soil changes have a strong influence on the local disposition of forest and peatland vegetation at any particular site.

\section{Acknowledgments}

This work was funded by research grants from the Department of Fisheries and Oceans and the Coastal Ecosystems Research Foundation, and an employment grant from the British Columbia Ministry of Environment, Lands, and Parks (E-Team). A. Walkus Jr., B. Kaytor, and A. Hanuse assisted with data collection. Y. Dolmat, C. Metti, N. Witherly, and B. Woodward provided logistical support. G. Bradfield and two anonymous reviewers provided many helpful comments on earlier versions of this paper.

Documents Cited (marked * in text citations)

Atmospheric Environment Service. 1982. Canadian Climate Normals 1951-1980 Temperature and Precipitation: British Columbia.

Lamb, E. G., Y. Dolmat, J. Holloway, K. Shankel, and W. Megill. 2000. Findings of the 1999 CERF Survey of Coastal Biodiversity on the Central Coast of British Columbia. Unpublished Report to DFO [Department of Fisheries and Oceans]. 114 pages.

Marshall, I. B., and P. H. Schut. 1999. A national ecological framework for Canada. Ecosystems Science Directorate, Environment Canada, and Research Branch, Agriculture and Agri-Food Canada.

\section{Literature Cited}

Banner, A., R. J. Hebda, E. T. Oswald, J. Pojar, and R. Trowbridge. 1988. Wetlands of Pacific Canada. Pages 304-346 in Wetlands of Canada. Edited by National Wetlands Working Group, Polyscience, Ottawa. 452 pages.

Banner, A., J. Pojar, and G. E. Rouse. 1983. Postglacial paleoecology and successional relationships of a bog woodland near Prince Rupert, British Columbia. Canadian Journal of Forest Research 13: 938-947.

Day, R. W., and G. P. Quinn. 1989. Comparisons of treatments after an analysis of variance in ecology. Ecological Monographs 59: 433-463.

Douglas, G. W., D. Meidinger, and J. Pojar. Editors. 1998, 1999, 2000, 2001, 2002. The Illustrated Vascular Plants of British Columbia. (8 Volumes). Province of British Columbia, Victoria.

Dufrêne, M., and P. Legendre. 1997. Species assemblages and indicator species: the need for a flexible asymmetrical approach. Ecological Monographs 67: 345-366.

Jungen, J. R., and T. Lewis. 1978. The Coast Mountains and islands. Pages 102-120 in The soil landscapes of British Columbia. Edited by K. W. G. Valentine, P. N. Sprout, T. E. Baker, and L. M. Lavkulich. Resource Analysis Branch, Ministry of the Environment, Victoria, British Columbia. 197 pages.

Kenkel, N. C., and L. Orlóci. 1986. Applying metric and nonmetric multidimensional scaling to ecological studies: some new results. Ecology 67: 919-928

Kent, M., and P. Coker. 1992. Vegetation description and analysis. John Wiley and Sons, West Sussex. 363 pages.

Klinger, L. F., S. A. Elias, V. M. Behan-Pelletier, and N. E. Williams. 1990. The bog climax hypothesis: fossil arthropod and stratigraphic evidence in peat sections from southeast Alaska, USA. Holarctic Ecology 13: 72-80. 
Klinka, K., V. J. Krajina, A. Ceska, and A. M. Scagel. 1989. Indicator plants of coastal British Columbia. UBC Press, Vancouver, British Columbia. 288 pages.

Krebs, C. J. 1989. Ecological methodology. Harper Collins Publishers, New York. 654 pages.

Lawrence, D. B. 1958. Glaciers and vegetation in southeastern Alaska. American Scientist 46: 89-122.

McCune, B., and J. B. Grace. 2002. Analysis of ecological communities. MjM Software Design, Gleneden Beach, Oregon.

McCune, B., and M. J. Mefford. 1999. PC-ORD: Multivariate analysis of ecological data. MjM Software Design, Gleneden Beach, Oregon.

Neiland, B. J. 1971. The forest-bog complex of southeast Alaska. Vegetatio 22: 1-64.

Pojar, J., K. Klinka, and D. A. Demarchi. 1991. Coastal Western Hemlock Zone. Pages 95-111 in Ecosystems of British Columbia. Edited by D. Meidinger, and J. Pojar. BC Ministry of Forests, Research Branch, Victoria. 380 pages.
Ryder, J. M. 1978. Geology, landforms, and surficial materials. Pages 11-34 in The soil landscapes of British Columbia. Edited by K. W. G. Valentine, P. N. Sprout, T. E. Baker, and L. M. Lavkulich. Resource Analysis Branch, Ministry of the Environment, Victoria, British Columbia. 197 pages.

Schofield, W. B. 1992. Some Common Mosses of British Columbia. Royal British Columbia Museum, Victoria, British Columbia. 394 pages.

Ugolini, F. C., and D. H. Mann. 1979. Biopedological origin of peatlands in South East Alaska. Nature 281: 366-369.

Vitt, D. H., D. G. Horton, N. G. Slack, and N. Malmer. 1990. Sphagnum dominated peatlands of the hyperoceanic British Columbia Coast: patterns in surface water chemistry and vegetation. Canadian Journal of Forest Research 20: 696-711.

Zach, L. W. 1950. A northern climax, forest or muskeg? Ecology 31: 304-306.

Received 9 March 2001

Accepted 8 December 2003 